\title{
Level of Student Effort Should Replace Contact Time in Course Design
}

\author{
Elizabeth A. McDaniel \\ National Defense University iCollege, \\ Washington, DC, USA
}

mcdaniele@ndu.edu

Executive Summary

The academic credit hour, developed over 100 years ago, does not accommodate online and other instructional innovations. The academic credit hour is an Industrial Age metric based on seattime, or contact time that faculty and students spend together in a classroom. Online education does not require that students and faculty be in the same place for teaching and learning to occur, and it does not necessarily fit a fifteen-week semester model. Instead of requiring that online educators articulate the equivalence of their model with the traditional model, a new framework based on level of student effort is proposed that will free faculty and instructional designers to be more innovative. As academic currency, the academic credit hour represents some level of engagement by students. It is not a measure of what they have learned or the academic quality of the educational experience in which they participated. To reframe the academic credit hour, the author proposes making "level of student effort" the foundation of the definition. If a one-credit course is designed to engage students for forty hours, a three-credit course is designed to engage students with the course content and outcomes for approximately 120 to 130 hours. Faculty can use their experience to estimate the time and effort needed by the typical student to engage successfully in each of the learning activities in a particular field, course, and program. Faculty and course designers can determine how and to what degree students will engage with the course content, through resources, projects, laboratory experiences, dialogue other students, etc., and the size of these activities in terms of expected student effort. Within clear parameters faculty and course designers have freedom to innovate in the facilitation of learning.

Keywords: instructional design, online courses, innovative higher education, academic credit hour, academic quality

\section{Introduction}

How can the academic credit hour model stretch to accommodate online instructional models that have no seat time and no lecture time? The academic credit hour is an Industrial Age metric

Material published as part of this publication, either on-line or in print, is copyrighted by the Informing Science Institute. Permission to make digital or paper copy of part or all of these works for personal or classroom use is granted without fee provided that the copies are not made or distributed for profit or commercial advantage AND that copies 1) bear this notice in full and 2) give the full citation on the first page. It is permissible to abstract these works so long as credit is given. To copy in all other cases or to republish or to post on a server or to redistribute to lists requires specific permission and payment of a fee. Contact Publisher@InformingScience.org to request redistribution permission. based on seat-time, or contact time that faculty and students spend together in a classroom. When students are not sitting in classrooms with professors for one hour a week for fifteen weeks during a typical semester, the academic credit model starts to unravel. Online education does not require that students and faculty be in the same place for teaching and learning to occur, and it does not necessarily fit a fifteen-week 
semester model. Recently one proprietary institution in the United States that awarded significantly more credits for instructional activities than those associated with traditional semester or quarter hour courses provoked the U.S. Department of Education to re-affirm the formula based on seat or contact time in classrooms (Lipka, 2010).

To reframe of the academic credit hour, the author proposes making "level of student effort" the foundation of the definition. The concept of level of student effort can validate and encourage innovative instructional approaches. One of its benefits is its alignment with the traditional credit paradigm on which higher education is based, while it accommodates online learning and fosters innovation. By focusing on learners and their time on task, it re-affirms learning as a critical measure of academic quality. Since growing numbers of educational providers offer online courses to thousands of undergraduate and graduate students in the United States and elsewhere in the world, a new framework for the academic credit is critical. Instead of requiring that online educators articulate the equivalence of their model with the traditional model, a new framework based on level of student effort is proposed that will free faculty and instructional designers to be more innovative. This revision of the academic credit model might catalyze important discussions among higher education stakeholders about academic quality.

\section{Relevance of the Academic Credit Hour Today}

At the beginning of the last century, American colleges collaborated to establish policies that guided the development of the higher education industry. In 1900, a handful of colleges created the College Entrance Examination Board to expand access to higher education by simplifying the application process for students and college admission offices. In 1905, Andrew Carnegie founded The Carnegie Foundation for the Advancement of Teaching. In 1906, by an Act of Congress it was chartered as an independent policy and research center whose primary activities are research and writing on every level of education. In 1909, the Carnegie unit was established based on the time to be spent on a subject, not the results (Shedd, 2003). This standard measure of high school coursework went on to become the academic credit hour or student credit hour used as the basis for evaluating costs, comparing institutional performance, and stimulating competition among member institutions of higher education.

In the last twenty years the landscape of higher education has changed in significant ways. In response to questions about value, costs, and quality from state legislators and federal policy makers, higher education has struggled to assess academic quality, particularly of innovative approaches. Higher education remains conservative, despite runaway costs, declining state support, uncertain quality, competition for qualified students, and public skepticism about its economic value.

The academic credit hour remains the building block of higher education. While it is amazingly flexible and durable, it perpetuates the factory model of higher education as a collection of units. Once students document successful completion of the requisite type and number they can graduate, thereby rewarding accumulation not learning (Wellman, 2005). Despite the diversity of American higher education, the academic credit hour is a constant within and across institutions. It facilitates mobility of students who wish to transfer credits from one institution to another, while undermining the value of coherent and integrated curricula (Erhlich, 2003).

\section{Higher Education's Reliance on the Academic Credit Hour}

Despite its importance, academics do not talk much about the academic credit hour. They think they agree on what it means. Institutions offer and faculty teach two- or three- or four-credit hour courses, and students collect academic credits toward degrees. Once students receive the required 
number, typically 120 , they can exit or graduate. But beyond that, most academics do not think much about academic credits especially related to course design.

With their years of experience in higher education faculty have been socialized in their disciplines. They have a general understanding of how to assign credits in the absence of clearly articulated institutional policies. Using this seat time-based measure of educational attainment, faculty members can determine the rigor, content, and assessment approaches that align with a specific number of credits. But two factors have challenged tradition. An initial unbundling of credit hours from rigid formulas of seat time and study time was precipitated by adult learners seeking equivalencies for their work and life experience and by advancements in educational technology.

As academic currency, the academic credit hour represents some level of engagement by students. It is not a measure of what they have learned or the academic quality of the educational experience in which they participated. The industry uses the academic credit hour as the basis for many of its academic and administrative functions (Shedd, 2003). "The Federal Government has been the single biggest regulator of the student credit hour as a time-based measure..." (Wellman \& Erlich, 2003). It is the basis for federal financial aid awards including eligibility for federal funding, loans, and grants which students use to pay tuition. Because it specifies the number of hours that students must be resident in class, it is the basis for scheduling of institutional academic terms and annual calendars. Faculty workloads for teaching and research derive from credit hours. Student time-to-degree, full-time and part-time status, enrollment monitoring, and graduation rates use credit hours. Funding by federal and state sources as well as budget allocations within institutions rely on student credit hour calculations as do the determination of the cost of degree programs, courses, laboratories, and other facilities. To comply with Federal regulations, regional accrediting agencies require institutional review when more than half of credits in an academic program are offered online (Wellman, 2005).

\section{The Academic Credit Hour Defined}

One academic credit hour is equal to one (50-minute) hour of classroom instruction plus two hours outside of the classroom of course-related work by students for fifteen weeks (of a semester). For a course to equal three credits, students and faculty must meet for three (50-minute) hours a week for fifteen weeks (37.5 hours total), and students must contribute six hours per week of outside work (Simonson, 2011).

In this way a three-credit hour course is a building block equivalent to $3 / 120^{\text {th }}$ of a typical baccalaureate degree. It is certification by the institution of a student's exposure to and/or engagement with a certain amount of knowledge, skills, and training. But it describes contact, not student learning or effort.

\section{Proposed Re-Formulation of the Academic Credit Hour}

In response to the now infamous proprietary online institution's violation of traditional relationship between time and the number of credits awarded to students, the U.S. Department of Education and regional accrediting agencies have returned their attention to the formulas that use classroom contact time as the foundation of the academic credit hour. This raises a question about the value of the Industrial Age factory model of the academic credit hour based on contact time in a classroom. According to Carol Twigg, President of the National Center for Academic Transformation, "the concept of a credit hour based on seat-time is a relic, but you have to have some kind of currency that can be traded" (DeVise, 2011).

An educational equivalency alternative to the academic credit hour that is not time based was proposed by Watkins and Schlosser $(2000,2003)$. Capabilities-Based Educational Equivalency 
(CBEE) units focus on attained knowledge and skills of learners rather than time in the classroom as a standardized measure of educational attainment based on taxonomies. While this innovation has educational merit, its runs into the same challenges of subjectivity and comparability as the larger assessment of learning movement when it seeks to evaluate programs and compare institutions.

Distance learning, enabled by new educational technologies, challenges time-based academic metrics like the credit hour. In well constructed online courses, students and faculty who never meet face-to-face in a classroom engage in dialogue, exploration, and creation more intensively than they do in a lecture hall. Small group and independent engagement, with or without an instructor, that may occur 24/7, offers opportunities for students to reflect on, apply, and integrate what they are learning.

Because the current student credit hour formula based on seat/contact time does not fit online instruction, institutions and faculty are required to justify the equivalencies of online instruction time and again. "We have hundreds of years of understanding what a credit hour represents, whether you're going to class or not going to class," says Carol Twigg. "The fact that it's called an hour is the problem" (Blumenstyk, 2010). The proposed change to the credit hour formula uses the level of student level in learning activities, not seat time. This approach allows professors and course designers to be innovative in their selection of learning activities that facilitate learning of the intended outcomes. Students engage with content through activities that require reading, writing, thinking, and reflection, alone and with the teacher and/or fellow students. Innovative delivery models and instructional strategies can leverage projects, assignments, fieldwork, interviews, exercises, games, laboratories, simulations, and scenarios to facilitate learning.

If a one-credit course is designed to engage students for forty hours, a three-credit course is designed to engage students with the course content and outcomes for approximately 120 to 130 hours. Faculty use their experience to estimate the time and effort needed by the typical student to engage successfully in each of the learning activities in a particular field, course, and program. For example, in the design of the course and its activities and assignments, the faculty member estimates how long it will take students to read and think, engage with activities and fellow students, and perform assessment tasks aligned with intended learning outcomes. These estimates reflect experience with these kinds of activities, the level of students, and the expected levels of mastery. Using these estimates, the designers of courses determine if students have the requisite time to meet course expectations.

An advantage of using student level of effort as a critical design variable is that formats and scheduling can take into consideration whether students are working while enrolled in courses, and whether students are taking more than one course at a time. If each course requires at least 120 hours of student effort, these hours must reasonably be accommodated in the course scheduling process so that learning outcomes can be achieved. For example, courses for adult students who are working full time must be scheduled over a longer period so that students have the necessary hours to commit to the course activities, assignments, and assessment. The expected level of student effort and schedule must also consider whether students are taking multiple courses, because there are only 24 hours in a day.

\section{Implications for the Design of Online and Resident Courses}

For all courses, including online courses, the course development process should begin with the intended learning outcomes. In many cases these come from courses that already exist in more traditional formats. Even if online courses are created for the first time in the online format, the experiences of experts are needed to determine the size and scope of the learning outcomes for 
particular students at the course level and their prior learning. As the goals for the educational experience, learning outcomes provide a framework for selecting the instructional approach and resources to facilitate learning. Near the conclusion of each particular course, successful learners are given opportunities to demonstrate new learning of the articulated learning outcomes at a specified level of mastery. The faculty and course designers determine how and to what degree students will engage with the course content, through resources, projects, laboratory experiences, dialogue other students, etc., and the size of these activities in terms of expected student effort. Within clear parameters faculty and course designers have freedom to innovate in the facilitation of learning.

The reframing of the academic credit unit with level of student effort at its base applies to face-toface instructional formats, hybrid ones, and online courses that have no face-to-face classroom engagement of faculty and students. The model can accommodate students who are able to achieve the outcomes with less time and effort, as well as others who may need to dedicate more time and effort.

\section{Conclusion}

The academic credit hour is not a measure of institutional quality or student learning. It is just an industrial carton that frames an educational experience of a certain size. While throwing out the academic credit hour or any reference to time on task has some appeal, it would cause many associated practices and processes to unravel. "The metrics based on the $\mathrm{SCH}$ (student credit hour) can be changed if there is a desire to do so. But it is probably unrealistic - and would be monumentally unproductive - to try to throw the unit out and start over" (Wellman, 2005, pp. 22-23). It is better to reframe the academic credit hour as the academic credit unit that aligns with the 100-year old model, existing industry practices, student and public common understandings, and faculty experiences and mental models.

This article proposes the replacement of classroom seat/contact time with level of student effort in the calculation of the academic credit unit. It recommends modification of the basic building block of higher education to allow for honest calculation of the academic credit and to foster innovation in instructional design by focusing on learning outcomes. By developing consensus about the meaning of the academic credit unit faculty and academic leaders can focus on learning outcomes for each course and program. They can also clearly communicate with students and other faculty about the student effort that is required to achieve those outcomes.

\section{References}

Blumenstyk, G. (2010, January 8). Beyond the credit hour: Old standards don't fit new models. The Chronicle of Higher Education, 56(17), A15.

DeVise, D. (2011, February 20). Getting higher education in shape. The Washington Post, pp. 12-22.

Ehrlich, T. (2003). The credit hour as a potential barrier to innovation: Lessons from innovative institutions. New Directions for Higher Education, 122, 31-43.

Lipka, S. (2010). Academic credit: Colleges' common currency has no set value. The Chronicle of Higher Education, 57(9). Retrieved from http://wiredcampus.chronicle.com/article/Academic-CreditColleges/124973/

Shedd, J. M. (2003). The history of the student credit hour. New Directions for Higher Education, 122, 512.

Simonson, M. (2011). A research need: Student time commitment and the three-semester credit online course. The Quarterly Review of Distance Education, 12(1), vii-viii. 
Watkins, R., \& Schlosser, C. (2000). Capabilities based educational equivalency units: Beginning a professional dialogue on useful models for educational equivalency. American Journal of Distance Education, 14(3) 34-47.

Watkins, R., \& Schlosser, C. (2003). It's not about time: A fresh approach to educational equivalency. TechTrends, 47(3), 35.

Wellman, J.V. (2005, July/August). Change, 37(4), 18-23.

Wellman, J. V., \& Erlich, T. (2003, September 26). Re-examining the sacrosanct credit hour. The Chronicle of Higher Education, 50(5), B.16.

\section{Biography}

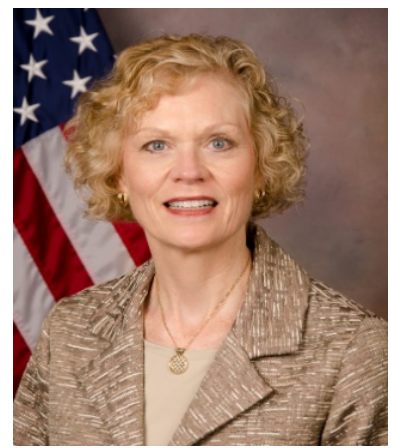

Elizabeth A. McDaniel is currently working on strategy and partnerships for the National Defense University iCollege. From August 2010 through July 2011 she was an NDU Fellow at the Information Technology Systems Division of the Institute for Defense Analyses. She served as the Dean of Faculty and Academic Programs at the Information Resources Management College, National Defense University from 1999 through 2010. After earning her Ph.D. from the University of Miami in 1978, she began her academic career at the University of Hartford, and advanced to full professor, and associate vice president for academic affairs. She was an American Council on Education Fellow in the Office of the President at the University of Connecticut in 1989-1990; Executive Provost and Vice President for Academic Affairs at Nova Southeastern University from 1995 to 1998; and Senior Fellow at the American Council on Education in 1998 -1999. 